\title{
Exploring the role of compactness in path-dependent land-taking processes in Italy
}

\author{
Francesco Orsi $®$
}

Accepted: 11 January 2022 / Published online: 29 January 2022

(C) The Author(s) 2022

\begin{abstract}
Land take, namely the conversion of natural land into impervious surfaces, is partly driven by path dependency, whereby dispersed settlements tend to spread more than compact ones over time. Yet there is limited knowledge about the extent to which specific aspects of compactness are associated with land take: a link that is instead crucial to formulate effective policies. This study investigates the impact of density, centrality, contiguity and degree of imperviousness by regressing land take data from 100 Italian NUTS3 administrative units for the period 2006-2012 against measures of the above-mentioned aspects as of 2006. Results indicate that higher shares of people in the 2000-2500 people $\mathrm{km}^{-2}$ density class, greater proximity of the population to urban centres, more contiguous urbanization patterns all help contain land take over time, whereas no significant effect was found for imperviousness. Increasing distance from protected areas reduces the positive effect of having more people live at densities of 2000-3000 people $\mathrm{km}^{-2}$, while steeper slopes enhance such effect. Planning interventions aimed at raising the share of
\end{abstract}

F. Orsi $(\bowtie)$

Landscape Architecture and Spatial Planning Group, Wageningen University and Research, Droevendaalsesteeg

3, Wageningen $6708 \mathrm{~PB}$, The Netherlands

e-mail: francesco.orsi@wur.nl

F. Orsi

Department of Geography and Geospatial Sciences, Kansas State University, Manhattan, KS 66506, USA people living at densities of 2000-2500 people $\mathrm{km}^{-2}$ as well as improving the degree of centrality or contiguity of urbanization patterns can lead to a decline in land take (measured as area of new land take per unit area of current land take) over a 6-year time span comprised between around 6 and 35\% depending on location. Further research is needed to confirm the validity of our results and explore the feasibility of such interventions.

Keywords Sprawl - Impervious surfaces · Density · Centrality $\cdot$ Contiguity

\section{Introduction}

Land take, namely the conversion of natural, seminatural and agricultural land into artificial surfaces (EEA, 2006), proceeds at alarming rates worldwide (UN, 2017a). In the European Union (EU) (including UK), for example, approximately $500 \mathrm{~km}^{2}$ of natural land (an area the size of Budapest, Hungary) have been lost every year between 2012 and 2018, and the extent of artificial land has increased by $6.7 \%$ between 2000 and 2018 compared to a 5\% population growth over the same period (EEA, 2020a). In the United States, the urban land area rose by $17 \%$ between 2002 and 2012 (from about 243,000 km² to $283,000 \mathrm{~km}^{2}$ ), almost twice as fast as population (Bigelow \& Borchers, 2017). In the previous decade, between 1990 and 2000, 14,000 $\mathrm{km}^{2}$ of open space 
had been lost within the 274 metropolitan areas of the lower 48 states (McDonald et al., 2010). Such trends constitute a serious threat to human well-being for they involve the consumption of limited natural resources-land and soil-that are key to the supply of crucial ecosystem services, including food production, carbon storage, nutrient cycling, habitat provision, water purification and flood mitigation (Dupras et al., 2016; Eigenbrod et al., 2011; Lorenz \& Lal, 2009; Pouyat et al., 2002; Sun et al., 2018; Suriya \& Mudgal, 2012).

The urgency of the problem has been formally acknowledged by the United Nations, which defined an ad hoc indicator-ratio of land consumption rate to population growth rate (11.3.1)-to monitor progresses toward the achievement of sustainable development goal 11 ("Make cities and human settlements inclusive, safe, resilient and sustainable") in the framework of the 2030 Agenda for sustainable development (UN, 2017b). On a strategic level, the European Commission (EC) has proposed to have policies in place by 2020 that aim to bring net land take down to zero by 2050 (EC, 2011). At the core of these policies, besides the idea of recycling areas that were once used and are now inactive, and that of compensating new constructions on natural land through renaturation of unused built-up areas, is the commitment to minimize new developments on unbuilt open space or agricultural areas (Science for Environment Policy, 2016). In order to design such policies, however, administrators and planners should not simply be able to assess the extent to which new developments can reasonably be made sustainable through infilling and renaturation, but they should also have a clear understanding of how current patterns of development may stimulate or restrain land take in the future. This is to avoid the promotion of forms of development that, while adding little to the current extent of artificial surfaces, may induce unintended expansions of such surfaces in the years to come owing to inertia in urbanization processes.

Over the last three decades, through both theoretical and empirical studies, scholars have acquired a deep knowledge on the drivers of land take (Colsaet et al., 2018). There is significant evidence, for example, that increasing levels of population growth (Deng et al., 2008; Marshall, 2007), income (Deng et al., 2008; Kuang et al., 2014; Weilenmann et al., 2017), proximity to transportation infrastructures
(Müller et al., 2010; Tian \& Wu, 2015), road density (Guastella et al., 2017; Oueslati et al., 2015) and administrative fragmentation (Carruthers, 2003; Wassmer, 2006) stimulate land take. Conversely, higher fuel prices (Ortuño-Padilla \& FernandezAracil, 2013), more protected areas (Irwin \& Bockstael, 2004; Zoppi \& Lai, 2014), urban growth boundaries (Wassmer, 2006) and steeper terrains (Christensen \& McCord, 2016; Deng et al., 2010; Müller et al., 2010) have been proven to limit land take. A relatively limited body of research has also explored path-dependent processes, namely dynamics by which past development affects future land take, mostly showing that higher density and greater compactness (i.e. less sprawl) today tend to foster comparably denser developments and less land take tomorrow (Burchfield et al., 2006; Paulsen, 2014; Siedentop \& Fina, 2012). Yet there is a substantial lack of information about the extent to which specific aspects of compactness may affect future land take. This is in fact highly relevant in the light of the multi-faceted nature of the compactness concept, which encompasses such diverse variables as population density, development contiguity, land use mix, etc. (Neuman, 2005).

First, previous studies have generally considered average population density over a territory (Zoppi \& Lai, 2014), but not the distribution of the population across different density classes, although the share of people living at low to medium urban densities is a very good indicator of sprawl in a region (Laidley, 2016; Lopez \& Hynes, 2003; Zambon \& Salvati, 2020). Second, little is known about whether the degree of centrality (i.e. the proximity of development to a central location such as a central business district or a major city), an important measure of compactness (Cutsinger et al., 2005; Galster et al., 2001; Kaza, 2020; Orsi, 2019), may trigger future land take. Third, while compact settlements are commonly characterized by contiguous development and a clear boundary between built-up and natural land (Heimlich \& Anderson, 2001; Neuman, 2005), there is no information about the effect of those elements on future land take. Fourth, previous studies have not investigated path-dependent processes related to the degree of imperviousness of built-up areas, a variable that is associated with soil sealing (Salvati, 2016) and therefore the ability of land to actually deliver ecosystem services (Haase \& Nuissl, 2007). 
This study aims to address the above research gaps by answering three research questions. Do the four above-mentioned aspects of compactness (population distribution, centrality, contiguity, imperviousness) at a given point in time have a significant association with land take over an upcoming period? Is the impact of such aspects on land take moderated by other determinants of land take? What is the potential for planning interventions targeting these aspects to actually contain land take in the future?

In order to answer these questions, land take occurring between 2006 and 2012 in Italian NUTS3 administrative units (relative to land take as of 2006) was regressed against different variables describing the four above-mentioned aspects of built-up areas as of 2006 while controlling for other determinants of land take. The study was conducted in Italy given the magnitude of land-taking processes the country has been experiencing over the last decades and the relevance of the topic in the national debate both at a policy (Munafo', 2020) and scientific (Munafo'et al., 2013; Pileri \& Maggi, 2010; Zoppi \& Lai, 2014) level. The focus on NUTS3 administrative units (equivalent to Italian provinces, namely administrative units including several municipalities), rather than single municipalities or cities, was meant to capture possible shifts in urban development from major to minor settlements within the same administrative and economic territory.

\section{Study area}

Italy has a total area of slightly over $301,000 \mathrm{~km}^{2}$, of which $7 \%\left(21,400 \mathrm{~km}^{2}\right)$ is currently covered by impervious surfaces (Munafo', 2020). Given a population of roughly 60 million, the amount of artificial land cover per capita is around $355 \mathrm{~m}^{2}$, which is in line with the EU average $\left(363 \mathrm{~m}^{2}\right)$ (Eurostat, 2020a). In terms of recent land take, Italy has added $954 \mathrm{~km}^{2}\left(16 \mathrm{~m}^{2}\right.$ per capita) of artificial surfaces in the 2000-2018 period (i.e. roughly a 5\% increase compared to $2000 \mathrm{lev}-$ els), although most of these in the 2000-2006 period (494 $\mathrm{km}^{2}$ or $8.2 \mathrm{~m}^{2}$ per capita) and the 2006-2012 period (356 $\mathrm{km}^{2}$ or $5.9 \mathrm{~m}^{2}$ per capita) (EEA, 2020b) (please note that land take data from EEA and Eurostat may not be perfectly comparable to data from national institutes, e.g. Munafo', 2020). While such growth is much lower than that of, among others, Spain $\left(53 \mathrm{~m}^{2}\right)$, the Netherlands $\left(38 \mathrm{~m}^{2}\right)$, France $\left(32 \mathrm{~m}^{2}\right)$ and the EU $\left(28 \mathrm{~m}^{2}\right)$, it is comparable to that of Germany and the United Kingdom (16 $\mathrm{m}^{2}$ for both), and higher than that of Belgium ( $9 \mathrm{~m}^{2}$ ) (EEA, 2020b).

Recent estimates show that net land take (i.e. new artificial surfaces minus renaturation of previously artificial land cover) in Italy is now progressing at 14.2 ha per day, slightly higher than what it used to be in 2015 (Munafo', 2020). Worryingly enough, most of this increase in artificial land cover (up to 90\%) is taking place in areas that would be highly suitable for agricultural practices (i.e. not too steep, outside protected areas, at low flooding and landslide risk), therefore jeopardizing food security of the local population (Gardi et al., 2015; Munafo', 2020).

Both land take per capita and land take increment vary considerably within Italy. The former is inversely related to population density, hence taking on low values in such dense regions as Lombardia $\left(286 \mathrm{~m}^{2}\right)$, Lazio $\left(235 \mathrm{~m}^{2}\right)$ and Campania $\left(240 \mathrm{~m}^{2}\right)$, and high values in such scarcely populated regions as Friuli-Venezia-Giulia $\left(519 \mathrm{~m}^{2}\right)$, Umbria $\left(501 \mathrm{~m}^{2}\right)$ and Basilicata $\left(554 \mathrm{~m}^{2}\right.$ ) (Munafo', 2020). The latter is particularly strong in the most economically dynamic part of the country (Lombardia, Veneto and Emilia-Romagna in the North), around Rome and Naples, and in Puglia and Sicily in the South (Munafo', 2020).

This research is conducted on NUTS3 administrative units, which are relatively small territories (mostly between 2000 and $4000 \mathrm{~km}^{2}$ ), one administrative level below the above-mentioned regions and corresponding to Provinces. The decision to pick this administrative level to obtain the statistical units for the study was driven by the goal of having a sufficiently high number of relatively uniform units that include both urbanized areas and countryside, therefore guaranteeing statistical robustness and a full appreciation of urban expansion phenomena. In fact, regions (NUTS2 administrative level) would be too few (20) and large, whereas municipalities are extremely heterogenous, with some being predominantly urbanized and some predominantly rural. 


\section{Method}

Data

The extent and spatial pattern of land take was extracted from the 2006 and 2012 Copernicus highresolution imperviousness density datasets, which report the degree of imperviousness $(\%)$ at 20 -m resolution for the whole Europe (https://land.copernicus. $\mathrm{eu} /$ ). These datasets were also used to compute the degree of imperviousness and to assess the shape of built-up areas. The boundaries of the NUTS3 administrative units were obtained from Eurostat in shapefile format (Eurostat, 2020b). Basic demographic and socioeconomic data such as population and GDP per NUTS3 unit were also available on the Eurostat portal (Eurostat, 2020c, 2020d). Information about population distribution was extracted from the GEOSTAT 2006 population-grid dataset, which reports the population census in a $1 \mathrm{~km}^{2}$ grid format. The identification of urban areas was based on the 2006 degree of urbanisation classification for Europe and the associated spatial datasets (Dijkstra \& Poelman, 2014). The road network was assembled by combining primary and secondary roads from the Global Roads Open Access Data Set (gROADS, v1 1980-2010) (CIESIN \& ITOS, 2013), with tertiary roads extracted from OpenStreetMap. The presence and shape of protected areas were derived from the shapefile of Natura 2000 sites, which is produced and updated by the European Environment Agency. Finally, the EU-DEM version 1.1 at $25-\mathrm{m}$ resolution produced by the Copernicus Land Monitoring Service (https://land.copernicus. $\mathrm{eu} /$ ) was used to compute slope.

\section{Variables}

The dependent variable is relative land take between 2006 and 2012, intended as $\mathrm{m}^{2}$ of artificial surfaces added in the 2006-2012 period per hectare of artificial surfaces existing in 2006. In fact, the natural logarithm of this is considered as a way to get a quasi-normally distributed variable, enhance the linear relation with the independent variables and reduce potential issues of heteroskedasticity. The extension of land take in 2006 was estimated by considering land parcels whose degree of imperviousness (ranging between 0 and 100\%) in that year was higher than zero as specified in the relevant spatial dataset (Fig. 1). The area of land taken between 2006 and 2012 was computed by identifying parcels of land that had a degree of imperviousness equal to zero in 2006 and higher than zero in 2012 (Fig. 1). Renaturation processes were not considered in the analysis, hence land parcels whose degree of imperviousness dropped from above zero in 2006 to zero in 2012 were simply disregarded.

All independent variables were computed as of 2006 given the explicit objective of providing knowledge about the extent to which urbanization patterns in a given year may affect land take over the following years. The sole exceptions to that are variables related to population and income change, which were considered as control variables (and computed as differences between 2006 and 2012 values) assuming that, when conducting predictive studies, practitioners could always extrapolate these from reliable future projections.

The effect of population distribution on future land take was tested using multiple variables reporting the shares of NUTS3 regions' population living at low to medium urban densities. In particular, the following ranges were considered: 300-500, 500-1000, 1000-1500, 1500-2000, 2000-2500 and 2500-3000 people $\mathrm{km}^{-2}$.

Centrality was measured as the average travel time (minutes) of a NUTS3 region's inhabitants to the closest urban area, as defined by the degree of urbanisation classification: namely, a cluster of contiguous grid cells of $1 \mathrm{~km}^{2}$ with a population above 5000 and a density of at least 300 people $\mathrm{km}^{-2}$ (Dijkstra \& Poelman, 2014). Travel time from any $1 \mathrm{~km}^{2}$ grid cell to the nearest urban area was computed through a cost distance operation assuming speeds of $120 \mathrm{~km} \mathrm{~h}^{-1}, 60 \mathrm{~km} \mathrm{~h}^{-1}, 40 \mathrm{~km} \mathrm{~h}^{-1}$ on primary (highways), secondary and tertiary roads, respectively. Average travel time was obtained as the summation of the products of travel time and population on a cell-by-cell basis divided by the overall population of a NUTS3 region, as follows:

Average travel time $=\frac{\sum_{i=1}^{n} t t_{i} \times p_{i}}{P}$

where $t t_{i}$ is travel time from grid cell $i$ to the nearest urban area, $p_{i}$ is the population of cell $i$ and $P$ is the overall population of the NUTS3 administrative unit. 
Fig. 1 Land take as of 2006 was computed from the imperviousness layer of 2006 through identification of pixels with imperviousness higher than zero. Land take in the period 20062012 was computed from the imperviousness layers of 2006 and 2012 through identification of pixels with imperviousness equal to zero in 2006 and higher than zero in 2012
Imperviousness 2006

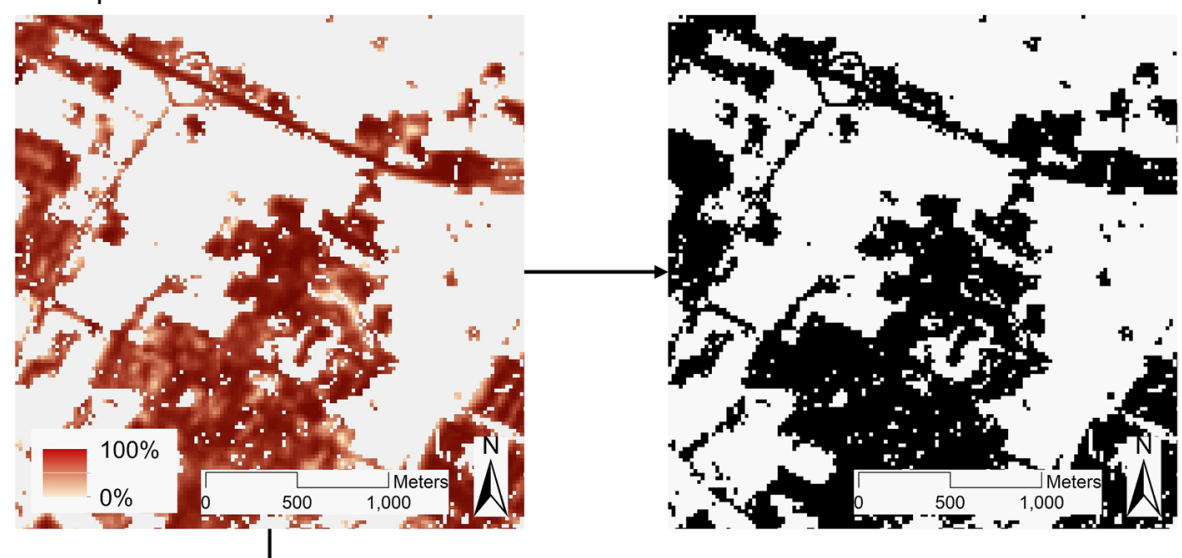

Land take 2006

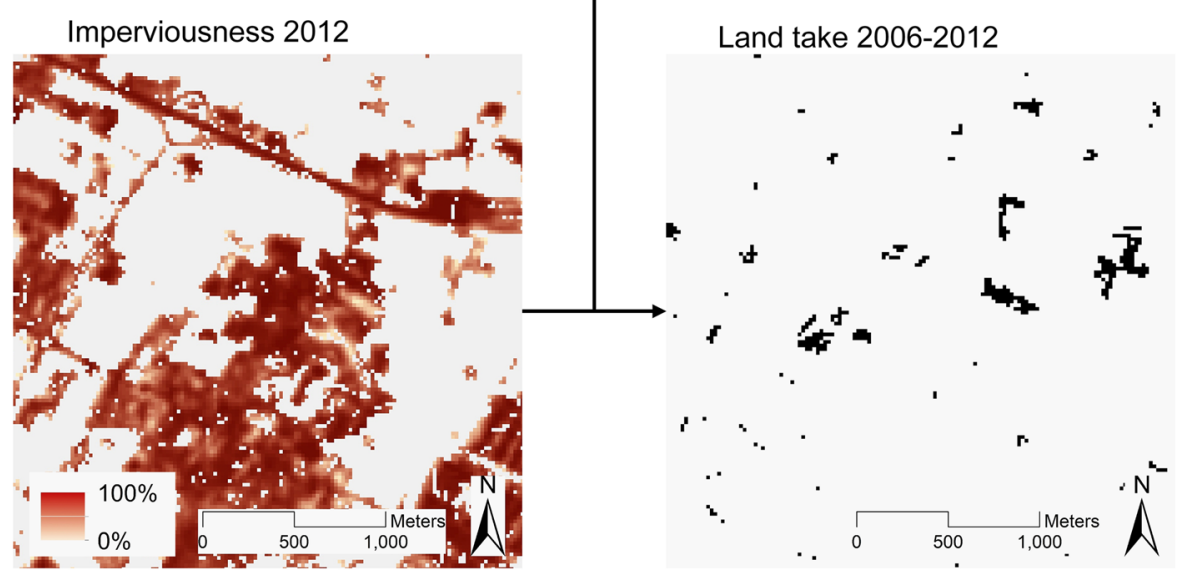

The contiguity of development and the blurriness of the interface between built-up and natural land were measured as the average number of builtup cells within a radius of $50 \mathrm{~m}$ around each built-up cell in a NUTS3 region. This was done by: reclassifying cells of the 2006 imperviousness map as either 1 (imperviousness greater than zero) or 0 (imperviousness equal to zero); running a neighborhood operation to compute the summation of cell values within a $100 \mathrm{~m} \times 100 \mathrm{~m}(5 \times 5$ cells $)$ around each cell; and calculating the average value across all built-up cells within a NUTS3 administrative unit. As shown in Fig. 2, the variable decreases whenever development gets more scattered and/or the boundary of the builtup area becomes less definite.

The degree of imperviousness was simply measured as the median, within a NUTS 3 region, of the imperviousness values of cells whose imperviousness is greater than zero. The median was chosen in lieu of the mean because it is less sensitive to extremes, therefore conveying more consistent information for areas characterized by relatively uniform imperviousness levels (e.g. a majority of high-imperviousness cells and few low-imperviousness cells).

Two common path dependency variables-population density and land take per capita-were included to have a reference against which to compare the explanatory power of the variables selected to measure the four characteristics presented above.

Finally, several variables were considered to control for well-known drivers of land take as suggested in literature. Among demographic and socioeconomic variables, we considered population in 2006, population change (\%) between 2006 and 2012, GDP per capita in 2006 and GDP per capita change (\%) between 2006 and 2012. In order to account for administrative fragmentation and governance conditions, the number of municipalities per $\mathrm{km}^{2}$ and the average distance of non-built-up land parcels (as of 2006) to protected areas were considered. 
Fig. 2 Measures of contiguity for four progressively less contiguous (from a to d) urbanization patterns. Contiguity was measured as the average number of builtup cells within a $5 \times 5$ filter around each built-up cell
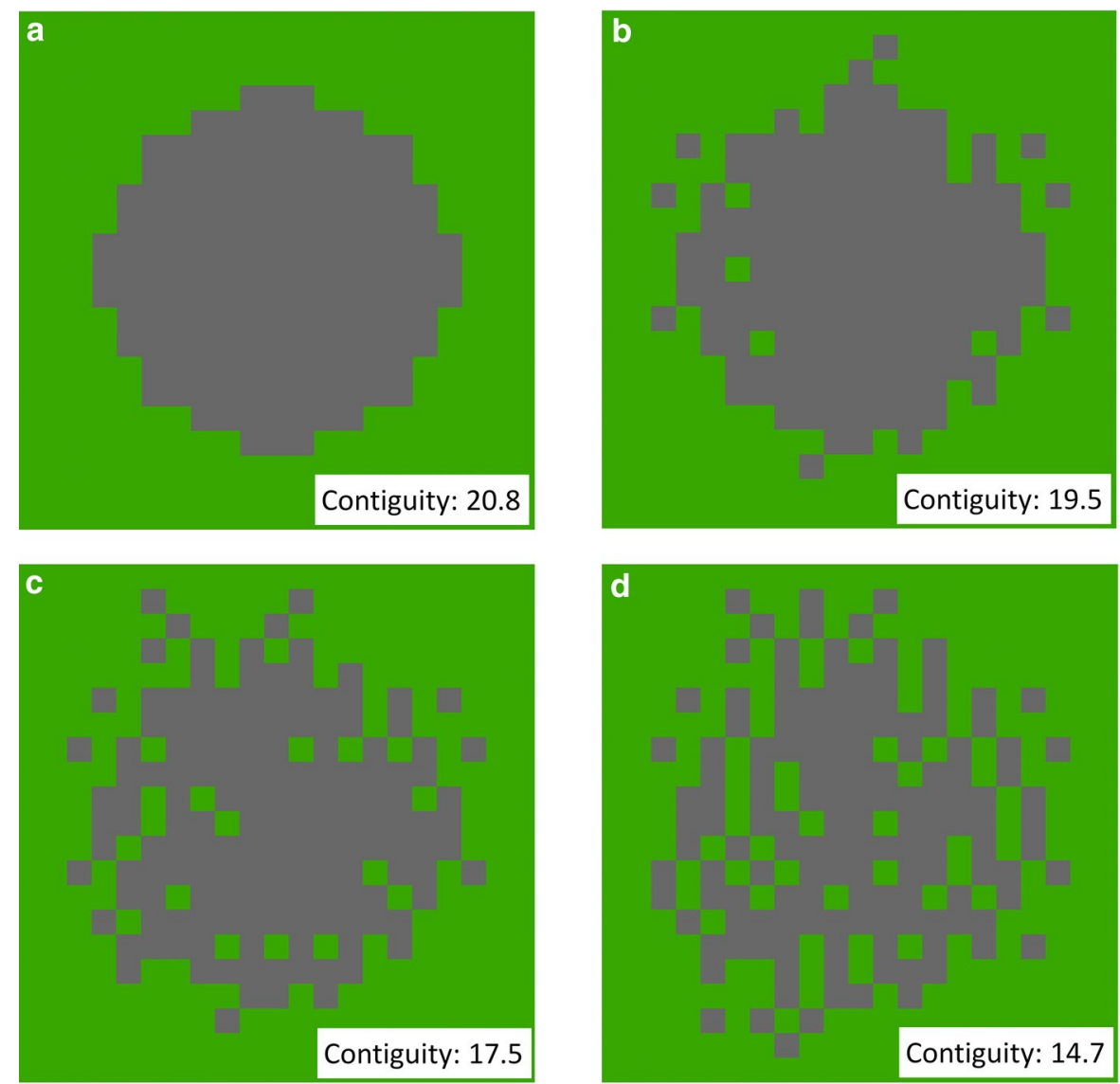

The average slope of non-built-up land parcels (as of 2006) was included to control for the impact of topography on land take. Finally, three binary dummy variables were included to account for intrinsic differences between Italian geographical macro areas NUTS3 administrative units belong to: North (including regions Valle d'Aosta, Piemonte, Lombardia, Liguria, Veneto, Trentino-Südtirol, Friuli-VeneziaGiulia, Emilia-Romagna), Center (including regions Toscana, Umbria, Marche, Lazio) and South (including regions Abruzzo, Molise, Campania, Puglia, Basilicata, Calabria, Sicilia). Given its unique location (i.e. far from mainland and not easily associable with either the Center or the South), the island of Sardegna was assumed to constitute a macro area of its own, to which no dummy variable was assigned (i.e. it was considered as base level for the other three dummy variables).

The actual number of statistical units included in the analysis (100) is lower than the number of Italian NUTS3 administrative units (110): that is because some units were removed for an excess of unclassified pixels in the 2006 imperviousness layer (Avellino, Biella, Cuneo, Imperia, Potenza, Savona), while others were removed for they present overly high density levels and a predominantly urbanized territory compared to the average (Milano, MonzaBrianza, Napoli, Trieste). Descriptive statistics of both dependent and independent variables, and Pearson coefficients of pairwise correlations between the dependent variable and all independent variables are presented in Tables 1 and 2, respectively. Raw values of the dependent variable (i.e. before log-transformation) for all NUTS3 administrative units considered in the analysis are shown in Fig. 3.

\section{Statistical analyses}

The first research question (Do the four aspects of compactness at a given point in time have a significant association with land take over an upcoming period?) was answered by regressing land take 
Table 1 Descriptive statistics of the variables

\begin{tabular}{|c|c|c|c|c|c|}
\hline Variable & $\begin{array}{l}\text { Number of } \\
\text { observations }\end{array}$ & Mean & Std. deviation & Minimum & Maximum \\
\hline Ln(land take growth) & 100 & 5.57043 & 0.739433 & 3.334364 & 6.925329 \\
\hline \multicolumn{6}{|l|}{ Control variables } \\
\hline Ln(population 2006) & 100 & 12.83245 & 0.70424 & 10.96467 & 15.15015 \\
\hline Pop. change 2006-2012 (\%) & 100 & 2.009653 & 2.400542 & -2.54598 & 6.66189 \\
\hline Ln(GDP per capita 2006) & 100 & 10.07005 & 0.25825 & 9.581904 & 10.53476 \\
\hline GDP per capita change 2006-2012 (\%) & 100 & -0.32438 & 5.812261 & -13.9456 & 13.76404 \\
\hline Municipalities per capita & 100 & 0.00019 & 0.000137 & $2.58 \mathrm{E}-05$ & 0.000597 \\
\hline Ln(distance from Natura2000) & 100 & 8.02353 & 0.479215 & 6.39708 & 9.201275 \\
\hline Slope & 100 & 9.5294 & 6.00368 & 0.32 & 26.69 \\
\hline North & 100 & 0.4 & 0.492 & 0 & 1 \\
\hline Center & 100 & 0.22 & 0.416 & 0 & 1 \\
\hline South & 100 & 0.3 & 0.461 & 0 & 1 \\
\hline \multicolumn{6}{|l|}{ Common path dependency variables } \\
\hline Density in 2006 (people $\mathrm{km}^{-2}$ ) & 100 & 194.3786 & 134.91454 & 31.02 & 710.53 \\
\hline Land take per capita in 2006 (ha) & 100 & 0.02783 & 0.0077 & 0.012 & 0.06243 \\
\hline \multicolumn{6}{|l|}{ Population distribution by density class } \\
\hline Share $300-500$ people $\mathrm{km}^{-2}(\%)$ & 100 & 9.008474 & 3.339795 & 3.23195 & 19.56683 \\
\hline Share $500-1000$ people $\mathrm{km}^{-2}(\%)$ & 100 & 16.1099 & 4.571303 & 5.008524 & 25.93521 \\
\hline Share $1000-1500$ people $\mathrm{km}^{-2}(\%)$ & 100 & 10.87943 & 3.109836 & 5.338615 & 18.89231 \\
\hline Share $1500-2000$ people $\mathrm{km}^{-2}(\%)$ & 100 & 8.37808 & 2.649716 & 3.417197 & 16.07023 \\
\hline Share $2000-2500$ people $\mathrm{km}^{-2}(\%)$ & 100 & 6.074359 & 2.86642 & 0 & 13.16663 \\
\hline Share $2500-3000$ people $\mathrm{km}^{-2}(\%)$ & 100 & 4.796346 & 2.5387 & 0 & 15.16866 \\
\hline \multicolumn{6}{|l|}{ Centrality } \\
\hline Average travel time to nearest town (min.) & 100 & 4.737131 & 3.918014 & 0.127054 & 21.76056 \\
\hline \multicolumn{6}{|l|}{ Fragmentation and boundary } \\
\hline $\begin{array}{l}\text { Avg. number built-up cells within } 5 \times 5 \text { window } \\
\text { Soil sealing }\end{array}$ & 100 & 17.32159 & 1.286556 & 14.61919 & 20.21022 \\
\hline Median imperviousness & 100 & 55.55 & 6.004 & 43 & 73 \\
\hline
\end{tabular}

between 2006 and 2012 against variables describing the four aspects and the control variables presented above. This was done by first developing a basic minimal model made up of a few significant and uncorrelated variables from the set of control variables presented in Sect. 3.2, and then individually testing the significance and contribution to the basic model of the variables describing the four aspects. This formally corresponds to testing the following alternative hypothesis,

$H_{a}: \beta_{j} \neq 0$

against the null hypothesis,
$H_{0}: \beta_{j}=0$

where $\beta_{j}$ is the regression parameter associated with variable $j$. As parameters were estimated using the Ordinary Least Squares (OLS) method, the OLS assumptions were verified. Among other things, the basic model was tested for spatial autocorrelation by computing the global Moran's I of the residuals according to the following formula:

$I=\frac{n}{S_{0}} \frac{\sum_{i=1}^{n} \sum_{j=1}^{n} w_{i, j} z_{i} z_{j}}{\sum_{i=1}^{n} z_{i}^{2}}$ 
Table 2 Pearson coefficients for correlations between the dependent variable and all independent variables

\begin{tabular}{|c|c|}
\hline Variable & $\rho$ \\
\hline \multicolumn{2}{|l|}{ Control variables } \\
\hline Ln(population 2006) & -0.121 \\
\hline Pop. change 2006-2012 (\%) & $0.18 *$ \\
\hline Ln(GDP per capita 2006) & $0.176^{*}$ \\
\hline GDP per capita change 2006-2012 (\%) & -0.016 \\
\hline Municipalities per capita & -0.06 \\
\hline Ln(distance from Natura2000) & $0.334 * * *$ \\
\hline Slope & $-0.349 * * *$ \\
\hline North & 0.096 \\
\hline Center & 0.109 \\
\hline South & $-0.296 * * *$ \\
\hline \multicolumn{2}{|l|}{ Common path dependency variables } \\
\hline Density in 2006 (people $\mathrm{km}^{-2}$ ) & -0.119 \\
\hline Land take per capita in 2006 (ha) & $0.188^{*}$ \\
\hline \multicolumn{2}{|l|}{ Population density } \\
\hline Share $300-500$ people $\mathrm{km}^{-2}(\%)$ & 0.048 \\
\hline Share 500-1000 people $\mathrm{km}^{-2}(\%)$ & 0.015 \\
\hline Share $1000-1500$ people $\mathrm{km}^{-2}(\%)$ & -0.003 \\
\hline Share $1500-2000$ people $\mathrm{km}^{-2}(\%)$ & -0.026 \\
\hline Share $2000-2500$ people $\mathrm{km}^{-2}(\%)$ & $-0.168^{*}$ \\
\hline Share $2500-3000$ people $\mathrm{km}^{-2}(\%)$ & 0.013 \\
\hline \multicolumn{2}{|l|}{ Centrality } \\
\hline Average travel time to nearest town (min.) & 0.142 \\
\hline \multicolumn{2}{|l|}{ Fragmentation and boundary } \\
\hline $\begin{array}{l}\text { Avg. number built-up cells within } 5 \times 5 \text { window } \\
\text { Soil sealing }\end{array}$ & -0.061 \\
\hline Median imperviousness & 0.099 \\
\hline
\end{tabular}

*Significance at the 0.10 level

**Significance at the 0.05 level

$* * *$ Significance at the 0.01 level

where $n$ is the number of features, $z_{i}$ is the deviation of the residual for feature $i$ from the mean, $w_{i, j}$ is the spatial weight between feature $i$ and $j$, and $S_{0}$ is as follows:

$S_{0}=\sum_{i=1}^{n} \sum_{j=1}^{n} w_{i, j}$

The second research question (Is the impact of the four aspects of compactness on land take moderated by other determinants of land take?) was answered by adding to the previously developed regression models interaction terms between each of the aspects

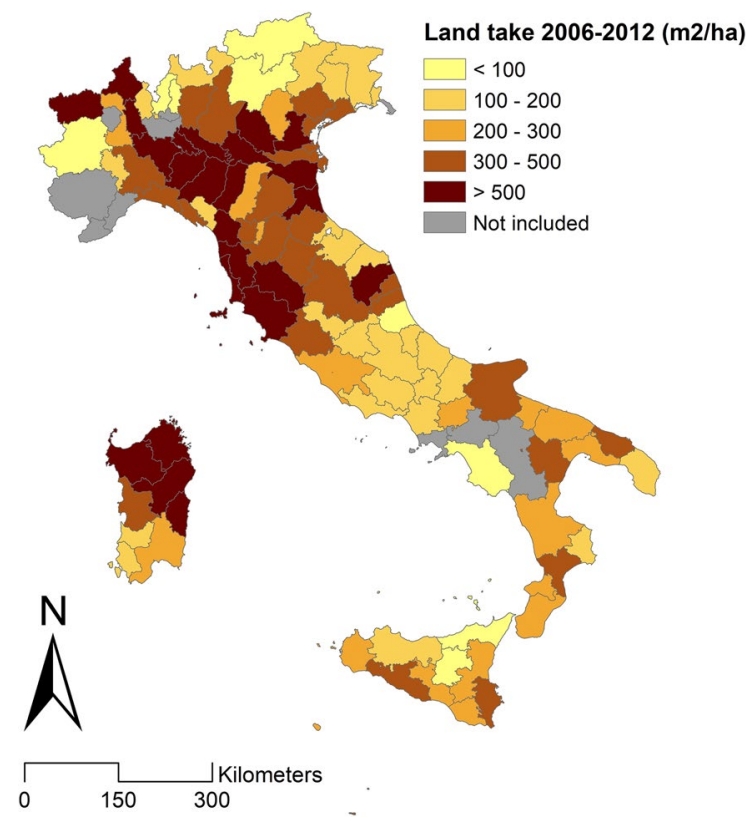

Fig. 3 Land take in the 2006-2012 period as $\mathrm{m}^{2}$ of natural land converted to impervious surfaces per hectare of impervious surfaces as of 2006. The natural logarithm of this variable was considered as the dependent variable for the statistical analyses

of compactness and the determinants of land take included in the basic model. Before the analysis, continuous predictors were mean-centered to avoid issues of multicollinearity.

The third research question (What is the potential for planning interventions targeting these aspects to actually contain land take in the future?) was answered by using the previously estimated regression coefficients of the statistically significant aspects of compactness to calculate, for each administrative unit, the decline in land take that would be associated with "reasonable" improvements in such aspects, similarly to what was done by Zoppi and Lai (2015). For a given administrative unit, the "reasonable" improvements were intended as land take restraining variations of the variables describing the above-mentioned aspects (i.e. increases or decreases depending on whether a variable is negatively or positively associated with land take) that are quantitatively compatible with levels of the same variables in nearby administrative units. This is based on the assumption that nearby administrative units present similar geographical and spatial planning characteristics, 
and that levels achieved by one unit on one variable can be reasonably achieved by the adjacent one. For each unit and each variable, the reasonable improvement was then computed as the standard deviation of values of the variable as measured in the unit and all neighboring units (i.e. units sharing the border). Only main effects were considered in the analysis: hence, calculated values represent decline in the dependent variable all else being equal and without any consideration of moderating effects by other predictors.

\section{Results}

Three predictors were eventually retained as control variables in the basic regression model used to test the effect of the four aspects of compactness on land take: distance from Natura 2000 areas, slope, south (Table 3). These cover the main categories of land take's determinants: regulation (i.e. development restrictions), environmental features and the economy (Southern regions showing, on average, lower levels of per capita income and economic growth than Central and Northern regions), respectively. The signs of regression coefficients associated with these variables are as expected: positive for the distance from Natura 2000 areas (the farther from protected areas the more land take), negative for the other two (land take is less where terrain is steeper and in Southern regions). Given the log-transformed dependent variable, regression coefficients are interpreted as elasticities or semi-elasticities depending on whether independent variables are also log-transformed or not. All else being equal, a $1 \%$ increase in the average distance of pervious land parcels from Natura 2000 areas is roughly associated with a $0.27 \%$ increase in relative land take between 2006 and 2012 compared to 2006 levels, one extra degree of average slope of pervious surfaces is associated with a roughly $4 \%$ decline $(\exp (-0.04)=0.96)$ in relative land take over the same period, whereas land take in the 2006-2012 period relative to absolute land take in 2006 is around $45 \%$ less $(\exp (-0.6)=0.55)$ in the South than elsewhere. The model satisfies all basic assumptions of the OLS, including lack of spatial autocorrelation of residuals as indicated by values of the Moran's I.

Looking at the two classical path-dependency variables, population density has a significant effect on land take, with every 100 extra people per $\mathrm{km}^{2}$ in 2006 reducing land take in the 2006-2012 period compared to 2006 levels by $10 \%$, whereas land take per capita does not. The adjusted $\mathrm{R}^{2}$ of the regression model including population density (column 1 in Table 3) tells the model explains $28.5 \%$ of the variance of the dependent variable and sets the standard against which to compare the explanatory power of variables selected to describe the four aspects of compactness.

Among variables chosen to estimate the effect of population distribution across density classes, only the share of people living at densities comprised between 2000 and 2500 people $\mathrm{km}^{-2}$ has a significant effect (column 7 in Table 3), whereby a $1 \%$ increase of such share is associated with a $5 \%$ decline in land take over the next 6 years compared to initial period levels. The adjusted $\mathrm{R}^{2}$ of this model (0.275) suggests the explanatory power of the share of people living in this density class is lower than that of an administrative unit's average population density. Although not significant, the signs of regression coefficients assigned to the other density classes disclose something interesting and meaningful: larger shares of people living at lower density levels (300-1500 people $\mathrm{km}^{-2}$ ) in 2006 are associated with more land take over the next six years, whereas larger shares of people living at higher density levels (1500-3000 people $\mathrm{km}^{-2}$ ) are associated with less land take.

The coefficient associated with the centrality variable is significant and has a positive sign (column 9 in Table 3), telling that every extra minute of average travel time to the nearest town in 2006 pushes the number of $\mathrm{m}^{2}$ of land take in the 2006-2012 period per hectare of artificial surface in 2006 up 3\%. The adjusted $\mathrm{R}^{2}$ in this case $(0.280)$ reveals an explanatory power nearly equal to that of average population density.

The coefficient associated with the contiguity variable is significant and negative (column 10 in Table 3), suggesting that a one-point increase in the average number of built-up cells within a 50-m radius around each built-up cell (i.e. a more contiguous fabric) is associated with a $12 \%$ decline in the amount of $\mathrm{m}^{2}$ of land take in the 2006-2012 period per hectare of land take as of 2006 . The adjusted $\mathrm{R}^{2}$ for this model (0.293) suggests the explanatory power of this variable is higher than that of average population density. 


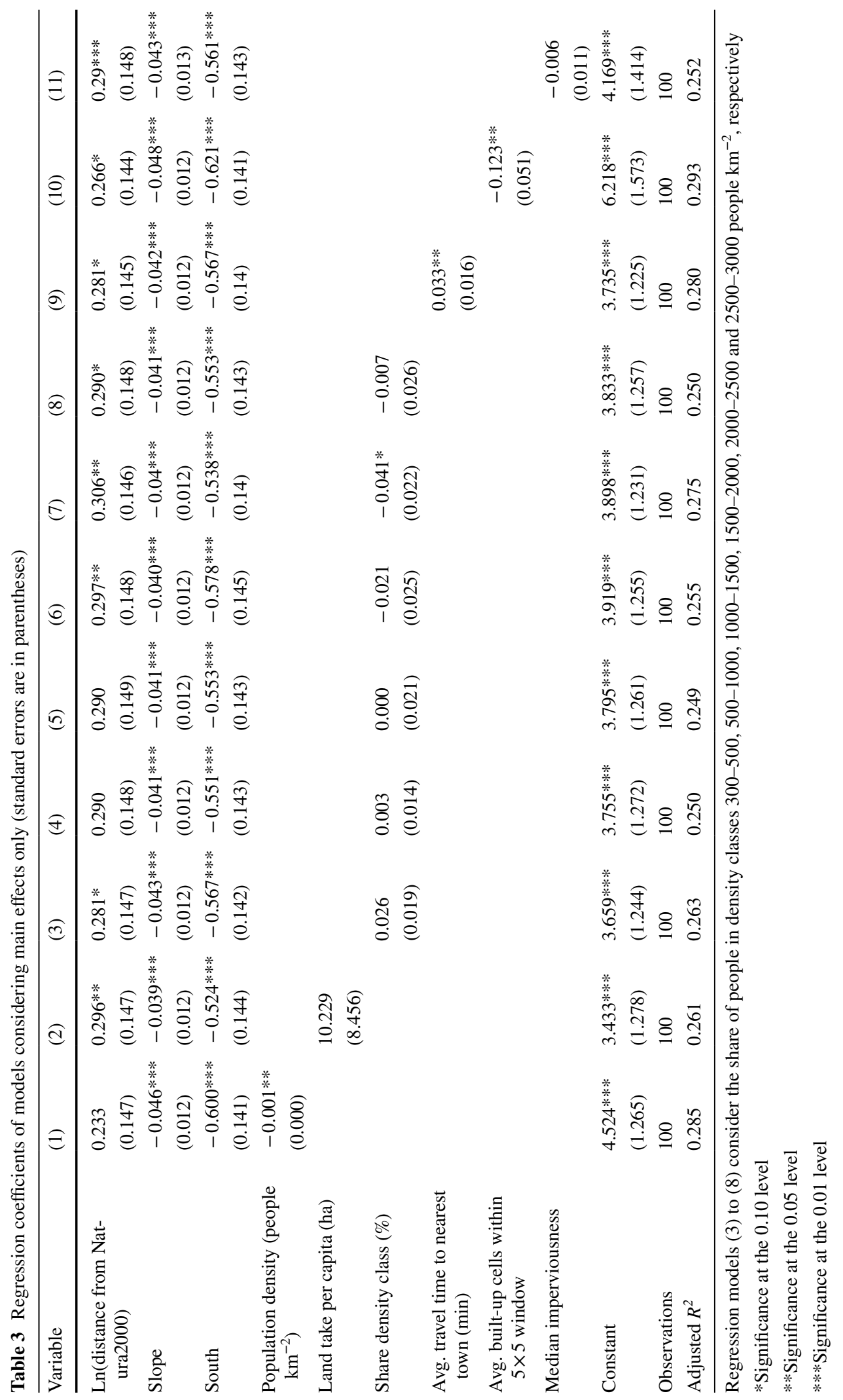


The coefficient associated with the imperviousness variable is not significant (column 11 in Table 3), preventing any consideration on the link between the current degree of imperviousness and future land take.

The analysis of interaction effects shows that slope and distance from Natura 2000 areas respectively moderate the impact of the shares of people in the 2000-2500 and 2500-3000 people $\mathrm{km}^{-2}$ on land take, whereas membership to a Southern region moderates the impact of imperviousness on land take (Table 4). An extra degree of average slope (e.g. a province whose pervious surfaces have an average slope of five degrees compared to one where average slope is four degrees) reduces the land take associated with one percent more people living in the 2000-2500 people $\mathrm{km}^{-2}$ density class by about $1 \%$. A one percent increment in the average distance from Natura 2000 areas increases the land take associated with one percent more people living in the 2500-3000 people $\mathrm{km}^{-2}$ density class by about $0.12 \%$. Being in a Southern region increases the land take associated with one extra point of median imperviousness by about $5 \%$. As the regression coefficient of the imperviousness variable in this case is nearly significant $(p<0.10)$ and negative $(-0.024)$, we can say that being in a Southern region reverses the effect of imperviousness on land take, whereby higher imperviousness levels stimulate, rather than restrain, land take.

The percent decline in $\mathrm{m}^{2}$ of additional land take per ha of current land take associated with improvements in the share of people living in the 2000-2500 people $\mathrm{km}^{-2}$ density class, the average travel time to towns and the contiguity of urban fabric (imperviousness was not considered because its effect on land take was found insignificant in the statistical analysis) is presented in Fig. 4, which also shows the supposedly most effective intervention for each NUTS3 administrative unit. In general, all interventions on the three aspects above might guarantee declines in land take over a 6-year horizon (compared to current levels of land take) that are comprised between about $6 \%$ and $35 \%$. Assuming an expected addition of impervious surfaces over the 6-year period of $300 \mathrm{~m}^{2}$ per hectare of land take at the start of the period, these interventions could then bring this figure down to values ranging between 282 and $195 \mathrm{~m}^{2}$ per hectare (i.e. a reduction between 18 and $105 \mathrm{~m}^{2}$ per hectare). Interventions on densification seem preferable in the North (particularly the area around Milan), interventions on centralization may be more effective in Toscana, some of the South (particularly Puglia and Northern Calabria) and most of the island of Sardegna, whereas interventions improving contiguity might be best in the Northwest and Northeast, most of the central part of the country and the island of Sicilia.

\section{Discussion and conclusion}

This study expands our knowledge on the role of compactness in path-dependent land-taking processes by showing that in Italian provinces population distribution across density classes, the spatial distribution of people over the landscape and the degree of contiguity of the urban fabric today are significant predictors of future land take. In particular, greater compactness today, in terms of higher shares of people living at medium densities, more clustering of the population around towns and cities, and a more contiguous urban fabric, help contain land take in the future.

Although six density classes were considered to fully describe population distribution from very low to medium urban densities, only the share of people in the 2000-2500 people $\mathrm{km}^{-2}$ class proved significant. This may be due to the fact that a considerable proportion of people living at such density levels generally implies large extents of a kind of urban environment (i.e. mid-rise buildings, moderate land use mix, proximity to services) that is unlikely to stimulate much expansion of impervious surfaces for the creation of dedicated transportation or commercial infrastructures. As a way of containing future land take, planners may then aim to promote these contexts, which can strike a decent balance between density and livability (Orsi, 2018). The signs of regression coefficients of the shares of people in the other density classes, though insignificant, suggest the existence of a density threshold at around 1500 people $\mathrm{km}^{-2}$, such that increasing the share of people who live at densities below this stimulates future land take. In many Italian settlements, this threshold marks a rather clear separation between the urban core (including not just historical city centres, but also many surrounding post-war developments) and the outer fringes, which are more fragmented and directly in contact with the countryside, and therefore more 
Table 4 Regression coefficients of models considering main and interaction effects

\begin{tabular}{|c|c|c|c|c|c|c|}
\hline Variable & (1) & (2) & (3) & (4) & $(5)$ & (6) \\
\hline Ln(distance from Natura2000) & $\begin{array}{l}0.252 \\
(0.152)\end{array}$ & $\begin{array}{l}0.277 * \\
(0.150)\end{array}$ & $\begin{array}{l}0.320 * * \\
(0.156)\end{array}$ & $\begin{array}{l}0.336 * * \\
(0.158)\end{array}$ & $\begin{array}{l}0.343 * * \\
(0.157)\end{array}$ & $\begin{array}{l}0.267 * \\
(0.149)\end{array}$ \\
\hline Slope & $\begin{array}{l}-0.043 * * * \\
(0.012)\end{array}$ & $\begin{array}{l}-0.041 * * * \\
(0.013)\end{array}$ & $\begin{array}{l}-0.037 * * \\
(0.014)\end{array}$ & $\begin{array}{l}-0.037 * * * \\
(0.013)\end{array}$ & $\begin{array}{l}-0.043^{* * *} \\
(0.012)\end{array}$ & $\begin{array}{l}-0.045^{* * *} \\
(0.012)\end{array}$ \\
\hline South & $\begin{array}{l}-0.551 * * * \\
(0.143)\end{array}$ & $\begin{array}{l}-0.541 * * * \\
(0.146)\end{array}$ & $\begin{array}{l}-0.561 * * * \\
(0.149)\end{array}$ & $\begin{array}{l}-0.605^{* * *} \\
(0.154)\end{array}$ & $\begin{array}{l}-0.534 * * * \\
(0.146)\end{array}$ & $\begin{array}{l}-0.575^{* * *} \\
(0.142)\end{array}$ \\
\hline Share density class $(\%)$ & $\begin{array}{l}0.029 \\
(0.025)\end{array}$ & $\begin{array}{l}0.005 \\
(0.018)\end{array}$ & $\begin{array}{l}0.008 \\
(0.026)\end{array}$ & $\begin{array}{l}-0.012 \\
(0.034)\end{array}$ & $\begin{array}{l}-0.016 \\
(0.031)\end{array}$ & $\begin{array}{l}-0.033 \\
(0.032)\end{array}$ \\
\hline $\begin{array}{l}\text { Avg. travel time to nearest town }(\mathrm{min}) \\
\text { Avg. built-up cells within } 5 \times 5 \text { window } \\
\text { Median imperviousness }\end{array}$ & & & & & & \\
\hline Ln(dist Nat2000) * Share density class & $\begin{array}{l}0.063 \\
(0.049)\end{array}$ & $\begin{array}{l}0.036 \\
(0.035)\end{array}$ & $\begin{array}{l}0.020 \\
(0.050)\end{array}$ & $\begin{array}{l}0.054 \\
(0.067)\end{array}$ & $\begin{array}{l}-0.023 \\
(0.044)\end{array}$ & $\begin{array}{l}0.116^{*} \\
(0.060)\end{array}$ \\
\hline Slope $*$ share density class & $\begin{array}{l}0.003 \\
(0.004)\end{array}$ & $\begin{array}{l}0.001 \\
(0.003)\end{array}$ & $\begin{array}{l}-0.001 \\
(0.005)\end{array}$ & $\begin{array}{l}0.000 \\
(0.004)\end{array}$ & $\begin{array}{l}-0.008 * * \\
(0.004)\end{array}$ & $\begin{array}{l}0.003 \\
(0.005)\end{array}$ \\
\hline South $*$ share density class & $\begin{array}{l}-0.007 \\
(0.044)\end{array}$ & $\begin{array}{l}0.008 \\
(0.034)\end{array}$ & $\begin{array}{l}-0.024 \\
(0.053)\end{array}$ & $\begin{array}{l}-0.013 \\
(0.059)\end{array}$ & $\begin{array}{l}-0.026 \\
(0.055)\end{array}$ & $\begin{array}{l}0.062 \\
(0.060)\end{array}$ \\
\hline $\begin{array}{l}\text { Ln(dist Nat2000)* Avg. travel time } \\
\text { Slope * Avg. travel time } \\
\text { South * Avg. traveltime } \\
\text { Ln(dist Nat2000) * Avg. built-up cells } \\
\text { Slope * Avg. built-up cells } \\
\text { South * Avg. built-up cells } \\
\text { Ln(dist Nat2000)* Imperviousness } \\
\text { Slope * imperviousness } \\
\text { South * imperviousness }\end{array}$ & & & & & & \\
\hline Constant & $\begin{array}{l}5.729 * * * \\
(0.078)\end{array}$ & $\begin{array}{l}5.734 \\
(0.078)\end{array}$ & $\begin{array}{l}5.738 \\
(0.078)\end{array}$ & $\begin{array}{l}5.748 * * * \\
(0.079)\end{array}$ & $\begin{array}{l}5.735 * * * \\
(0.076)\end{array}$ & $\begin{array}{l}5.738 * * * \\
(0.077)\end{array}$ \\
\hline Observations & 100 & 100 & 100 & 100 & 100 & 100 \\
\hline Adjusted $R^{2}$ & 0.255 & 0.237 & 0.230 & 0.240 & 0.291 & 0.263 \\
\hline Variable & & $(7)$ & & $(8)$ & & (9) \\
\hline Ln(distance from Natura2000) & & $\begin{array}{l}0.242 \\
(0.155)\end{array}$ & & $\begin{array}{l}0.252 \\
(0.152)\end{array}$ & & $\begin{array}{l}0.124 \\
(0.158)\end{array}$ \\
\hline Slope & & $\begin{array}{l}-0.042 * * * \\
(0.012)\end{array}$ & & $\begin{array}{l}-0.048 * * * \\
(0.012)\end{array}$ & & $\begin{array}{l}-0.044 * * * \\
(0.012)\end{array}$ \\
\hline South & & $\begin{array}{l}-0.550 * * * \\
(0.143)\end{array}$ & & $\begin{array}{l}-0.584 * * * \\
(0.144)\end{array}$ & & $\begin{array}{l}-0.505^{* * *} \\
(0.145)\end{array}$ \\
\hline \multicolumn{7}{|l|}{ Share density class $(\%)$} \\
\hline Avg. travel time to nearest town (min) & & $\begin{array}{l}0.032 \\
(0.019)\end{array}$ & & & & \\
\hline Avg. built-up cells within $5 \times 5$ window & & & & $\begin{array}{l}-0.123^{*} \\
(0.062)\end{array}$ & & \\
\hline Median imperviousness & & & & & & $\begin{array}{l}-0.024^{*} \\
(0.012)\end{array}$ \\
\hline
\end{tabular}


Table 4 (continued)

\begin{tabular}{|c|c|c|c|}
\hline Variable & (7) & (8) & (9) \\
\hline \multicolumn{4}{|l|}{ Ln(dist Nat2000) $*$ Share density class } \\
\hline \multicolumn{4}{|l|}{ Slope $*$ Share density class } \\
\hline \multicolumn{4}{|l|}{ South * Share density class } \\
\hline \multirow[t]{2}{*}{ Ln(dist Nat2000) $*$ Avg. travel time } & 0.027 & & \\
\hline & $(0.034)$ & & \\
\hline \multirow[t]{2}{*}{ Slope $*$ Avg. travel time } & -0.001 & & \\
\hline & $(0.004)$ & & \\
\hline \multirow[t]{2}{*}{ South $*$ Avg. travel time } & 0.004 & & \\
\hline & $(0.042)$ & & \\
\hline \multirow[t]{2}{*}{ Ln(dist Nat2000) * Avg. built-up cells } & & -0.068 & \\
\hline & & $(0.105)$ & \\
\hline \multirow[t]{2}{*}{ Slope * Avg. built-up cells } & & -0.010 & \\
\hline & & $(0.009)$ & \\
\hline \multirow[t]{2}{*}{ South $*$ Avg. built-up cells } & & 0.073 & \\
\hline & & $(0.131)$ & \\
\hline \multirow[t]{2}{*}{ Ln(dist Nat2000) $*$ Imperviousness } & & & -0.015 \\
\hline & & & $(0.024)$ \\
\hline \multirow[t]{2}{*}{ Slope $*$ imperviousness } & & & 0.004 \\
\hline & & & $(0.002)$ \\
\hline \multirow[t]{2}{*}{ South * imperviousness } & & & $0.054 * *$ \\
\hline & & & $(0.026)$ \\
\hline \multirow[t]{2}{*}{ Constant } & $5.736 * * *$ & $5.736 * * *$ & $5.776 * * *$ \\
\hline & $(0.077)$ & $(0.078)$ & $(0.079)$ \\
\hline Observations & 100 & 100 & 100 \\
\hline Adjusted $R^{2}$ & 0.265 & 0.290 & 0.283 \\
\hline
\end{tabular}

Regression models (1) to (6) consider the share of people in different density classes

Regression coefficients of models considering main and interaction effects (standard errors are in parentheses)

prone to further expansions. This is also consistent with the European Commission's harmonised definition of cities and rural areas, going under the name of "new degree of urbanisation" (Dijkstra \& Poelman, 2014), which sets exactly at 1500 people $\mathrm{km}^{-2}$ the density level above which are city centres.

The positive association between the centrality variable and land take affords some considerations on both the ratio of urban to rural dwellers and the accessibility of urban centres. On the one hand, assuming the utilized definition of urban area is appropriate (an area of at least 5000 people living at densities above 300 people $\mathrm{km}^{-2}$ ) (Dijkstra \& PoeIman, 2014), the more people live in a rural context, and hence at some distance from an urban area, the more land take we can expect in the future. While this is in conflict with studies detecting a positive correlation between increases in urban population and land take (Angel et al., 2011; Zhang \& Su, 2016), it is perfectly consistent with the idea that smaller fragments of built-up land may become the seeds of future developments. This is in fact what happens in Italy, where spontaneous developments around historical structures in rural settings, also called "sprinkling" (Romano et al., 2017a), are well-known and may have worse consequences than traditional sprawl (Romano et al., 2017b). On the other hand, the farther people live from urban centres, in terms of time needed to get there, the more land take we can expect in the future. This is also counterintuitive in the light of location theory (Alonso, 1964) and the notorious positive association between land take and accessibility (Braimoh \& Onishi, 2007), yet it is consistent with the idea that isolated communities expand through 
a
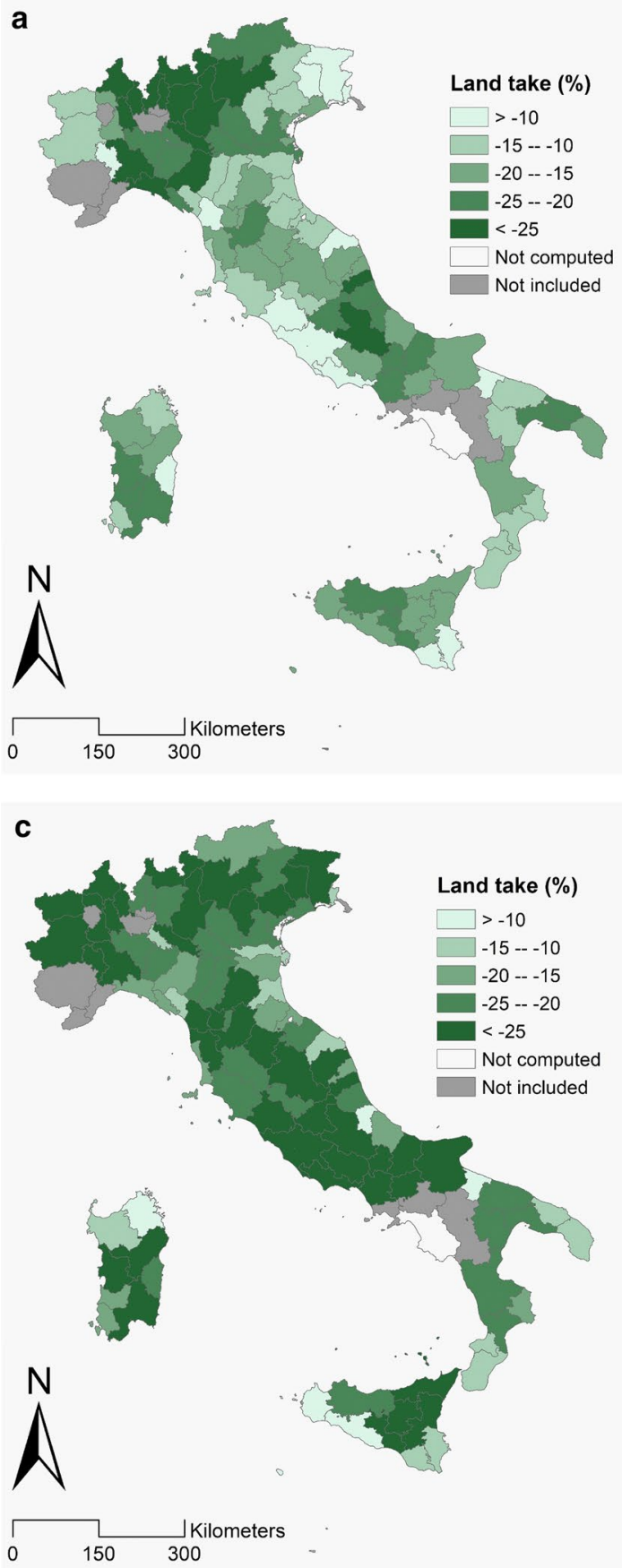

Fig. 4 Potential reduction in land take over a 6-year time span owing to interventions on the distribution of people across density classes (a); the proximity of the population to urban centres (b); the contiguity of urbanization patterns (c); and intervention likely to guarantee the greatest reduction in b
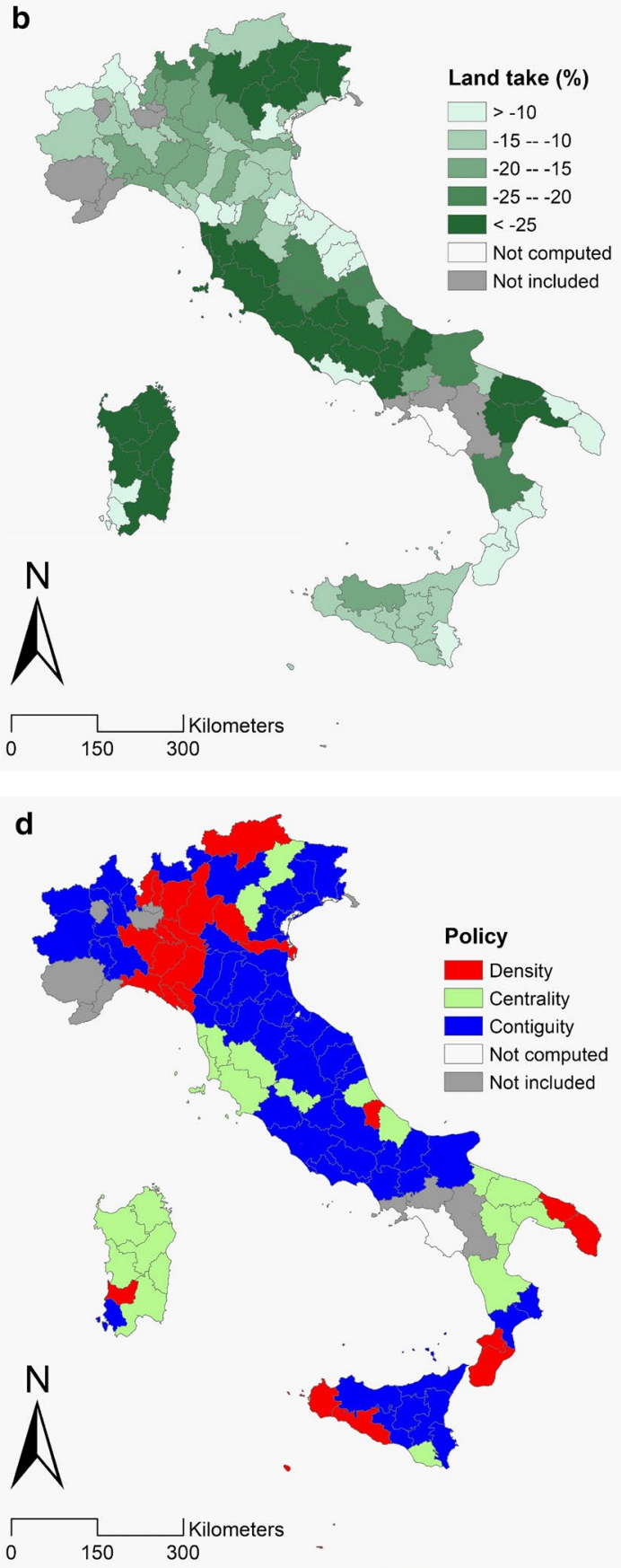

each administrative unit (d). Values were not computed for the Province of Avellino (shown in white) as none of its neighbors were included in the analysis due to incomplete information on imperviousness in 2006 
more land-intensive developments given lower land prices. Moreover, the fact that the variable adopted to measure centrality (per capita travel time to nearest urban centre) is poorly correlated with the size of a NUTS3 administrative unit $(\rho=0.22)$, suggests these considerations hold true no matter the context. From a planning perspective, it is then important to make sure that most new developments take place in and around cities and that small isolated communities do not grow excessively.

The coefficient of the contiguity variable complements findings by Burchfield et al. (2006): it is not just development on unincorporated land (i.e. areas beyond the municipal boundary, where planning regulations are lacking or weaker) that induces more sprawl and therefore land take, but also just poorly contiguous development. Considering how the variable was measured (i.e. $100 \mathrm{~m}$ x $100 \mathrm{~m}$ filter detecting the amount of built-up cells around each built-up cell), we can say that even micro-scale lack of contiguity, such as a rough city boundary, might induce a considerable expansion of impervious surfaces over time. As lack of contiguity is generally the outcome of weak spatial planning, our findings are consistent with a vast literature pointing to a negative association between regulation and land take (Burchfield et al., 2006; Huang et al., 2009; Nuissl \& SchroeterSchlaack, 2009; Wang et al., 2017). From a policy perspective, this is a call for a strong and unitary spatial planning that prevents voids and leapfrogging as these can then stimulate land-intensive ancillary developments.

Results suggest the explanatory power of the above-mentioned variables is comparable or even higher than that of average population density, a common predictor of path-dependent land-taking processes. We found population density to be inversely related to land take, in line with previous studies considering the number of people per area of sealed land (Siedentop \& Fina, 2012) or housing density (McDonald et al., 2010; Paulsen, 2014), but in conflict with findings by Zoppi and Lai (2014) and Zoppi and Lai (2015), who considered average population density too. This may be due to the choice of the dependent variable, which in the latter studies was the percentage of an administrative unit's area changing from non-artificial to artificial status, whereas in this study was the additional land take over the monitored period as a proportion of land take at the start of the period.

The significance of the selected compactnessrelated variables was tested in a model that controlled for basic determinants of land take including regulation (distance from Natura 2000 areas), geography (slope) and the economy (South). Regression coefficients for these predictors are consistent with the literature, whereby the distance from protected areas is positively (or the extent of protected areas is negatively) associated with land take (Zoppi \& Lai, 2014), slope is negatively associated with land take (Christensen \& McCord, 2016; Zoppi \& Lai, 2014) and income (which is lower in the South) is positively associated with land take (Angel et al., 2011; Deng et al., 2008, 2010). In fact, while the binary variable South can account for the major economic gap between the North-Center and the South, it may have also captured a wider array of aspects varying significantly between these two parts of the country, including the density of transport infrastructures, the extent of industrial areas and the impact of planning regulations. Purely monetary variables, such as GDP per capita and growth of GDP per capita, proved either poorly significant or badly affected by the 2008 financial crisis, and were therefore deemed unsuitable for the basic model.

Results of the analysis of interaction effects conducted to answer the second research question, though limited, have nonetheless some relevant planning implications. Increasing distances from, or a smaller extension of, protected areas may reduce the land take restraining power of having a higher share of people in a medium to high density class, whereas steeper slopes can enhance such power. This highlights the importance of establishing protected areas particularly in flat territories as a way to ensure housing policies aimed at increasing the share of people in medium to high density classes can actually deliver their calming effect on land-taking processes over time. The location of an administrative unit seems to have an effect on the impact of the median level of imperviousness, with land-taking processes being slowed down by higher degrees of imperviousness in the North-Center and being accelerated in the South. This might reflect more land take around large extensions of low-imperviousness peri-urban areas (e.g. low-density suburbs, business parks) in 
the North-Center and around completely filled (and therefore highly impervious) urban areas in the South.

Results of the analysis conducted to answer the third research question, though purely theoretical, show that intervening now on population distribution across density classes, centrality and contiguity may allow a significant containment of land-taking processes in the future. A $6 \%$ land take reduction, the minimum any of these measures might achieve, implies that an average province, with 12,000 hectares of land take at the start of the period and an expected $300 \mathrm{~m}^{2}$ of extra land take per hectare of initial land take, could spare 21.6 hectares (or more than a fifth of a $\mathrm{km}^{2}$ ) of natural land over the next 6 years. Under the most optimistic scenario, figures might be 6 times higher. The magnitude of these land take reductions depends on the combination of measure adopted (e.g. increasing the share of people living in a mid-density context vs. enhancing centrality) and improvement that is possible in a given province. We assumed the latter to be approximated by the performance of neighboring administrative units, though this may over- or underestimate the achievable improvement in case one or more of the neighbors present peculiar historical, social, governmental or geographical conditions that have allowed particularly high or low levels of the variables describing the three aspects. These results have to be considered merely theoretical for another couple of reasons though. First, the proposed interventions on density, centrality and contiguity may prove impossible in a given province for practical reasons (e.g. lack of funding, planning regulations, market conditions, people's preferences). Second, the elasticity values measured through the OLS model hold true over a limited range around the mean, while they may be rather biased for marked improvements on any of the three aspects.

In addition to those already mentioned in previous paragraphs, this study has further limitations that are due to specific methodological choices. Among empirical studies on the determinants of land take and urban sprawl, this is in fact one of very few (Burchfield et al., 2006; Paulsen, 2014) to regress the extent of land take or the degree of sprawl at the end of a period against urbanization patterns at the start of the period as a way to capture path-dependent processes. The fact that variables chosen to measure the four aspects of compactness were computed based solely on conditions as of
2006 (i.e. no consideration of where development took place between 2006 and 2012), though contributing to making our findings "policy-ready" (i.e. knowing current urbanization patterns, policy-makers can use our estimates to predict their impact on future land take), may have reduced the goodnessof-fit of the model.

As to the above-mentioned four variables, each of them has some weakness. The effect of population distribution was investigated using a set of classes that may not perfectly reflect different living environments throughout the country. Centrality only accounted for access to cities at large, while largely disregarding attraction flows to the main services, which may be decentralized but still foster land take. Contiguity was measured through an ad hoc variable that is based on an assessment of the land use pattern within a 50-m radius, although fragmentation may be better detected using other radii. Imperviousness was summarized using a statistic (i.e. median) that can hardly capture how it actually varies throughout a NUTS3 region.

Another important methodological decision behind this study regards statistical units, which are not cities or metropolitan areas (Burchfield et al., 2006; Paulsen, 2014), but small regions encompassing urban and rural areas as well as uninhabited territories. While this decision allowed us to (at least quantitatively) capture shifts of development between city and countryside, it has certainly made the interpretation of results difficult (i.e. harder to speculate where certain urbanization patterns encourage further development). As a side note, the use of these larger statistical units also forced us to work with a relatively small sample size $(n=100)$ : something that may have reduced the number of significant parameters obtained, but that certainly gives even more credibility to the significant ones. In fact, the sample size was smaller than anticipated because some statistical units had to be eliminated for either lack of data or their outlier nature. While units eliminated for the former reason are a minor issue, those eliminated for the latter reason may have affected the results because they represent some of the most economically dynamic areas in Italy (therefore likely experiencing strong increases in land take). Their elimination was unavoidable, however, because the minimal difference between urbanized area and overall area characterizing them 
(and somehow fostering more compact development) puts them on an entirely different level compared to all others.

Being almost entirely based on European-level data, the methodology adopted in this study is easily replicable in any other European country, although context-specific considerations may be needed for the definition of ad hoc control variables (e.g. binary variables defining different geographical regions) and the interpretation of results. Application of the method in other contexts instead may be thwarted by lack of high-resolution land cover data, which would make the estimation of land take and the assessment of contiguity and imperviousness largely inaccurate.

The findings of this study corroborate the notion that, when it comes to land take and urban sprawl, past development affects future conditions. Having quantified the impact of density, centrality and contiguity on the future expansion of impervious surfaces, it gives policy-makers some reference about which land take reductions they can reasonably expect from intervening on each of these aspects. Further research is needed to confirm the validity of our results and to figure out the feasibility of interventions on the aspects above.

Acknowledgements Two anonymous reviewers commented on an earlier version of the manuscript.

\section{Declarations}

Conflict of interest The author has no relevant financial or non-financial interests to disclose.

Human or animal rights My research does not involve any human or animal participant.

Open Access This article is licensed under a Creative Commons Attribution 4.0 International License, which permits use, sharing, adaptation, distribution and reproduction in any medium or format, as long as you give appropriate credit to the original author(s) and the source, provide a link to the Creative Commons licence, and indicate if changes were made. The images or other third party material in this article are included in the article's Creative Commons licence, unless indicated otherwise in a credit line to the material. If material is not included in the article's Creative Commons licence and your intended use is not permitted by statutory regulation or exceeds the permitted use, you will need to obtain permission directly from the copyright holder. To view a copy of this licence, visit http://creativecommons.org/licenses/by/4.0/.

\section{References}

Alonso, W. (1964). Location and land use. Cambridge, MA, USA: Harvard University Press.

Angel, S., Parent, J., Civco, D. L., Blei, A., \& Potere, D. (2011). The dimensions of global urban expansion: Estimates and projections for all countries, 2000-2050. Progress in Planning, 75(2), 53-107. https://doi.org/10. 1016/j.progress.2011.04.001

Bigelow, D.P., \& Borchers, A. (2017). Major uses of land in the United States, 2012, EIB-178, U.S. Department of Agriculture, Economic Research Service. https://www.ers. usda.gov/publications/pub-details/?pubid $=84879$

Braimoh, A. K., \& Onishi, T. (2007). Spatial determinants of urban land use change in Lagos, Nigeria. Land Use Policy, 24(2), 502-515. https://doi.org/10.1016/j.landusepol. 2006.09.001

Burchfield, M., Overman, H. G., Puga, D., \& Turner, M. A. (2006). Causes of sprawl: A portrait from space. The Quarterly Journal of Economics, 121(2), 587-633. https:// doi.org/10.1162/qjec.2006.121.2.587

Carruthers, J. I. (2003). Growth at the fringe: The influence of political fragmentation in United States metropolitan areas. Papers in Regional Science, 82, 475-499. https:// doi.org/10.1007/s10110-003-0148-0

Christensen, P., \& McCord, G. C. (2016). Geographic determinants of China's urbanization. Regional Science and Urban Economics, 59, 90-102. https://doi.org/10.1016/j. regsciurbeco.2016.05.001

CIESIN \& ITOS. (2013). Global roads open access data set, version 1 (gROADSv1). Center for international earth science information network, Columbia University, Information technology outreach services, University of Georgia. Palisades, NY: NASA Socioeconomic Data and Applications Center (SEDAC). https://sedac.ciesin.columbia.edu/ data/set/groads-global-roads-open-access-v1.

Colsaet, A., Laurans, Y., \& Levrel, H. (2018). What drives land take and urban land expansion? A systematic review. Land Use Policy, 79, 339-349. https://doi.org/10.1016/j.landu sepol.2018.08.017

Cutsinger, J., Galster, G., Wolman, H., Hanson, R., \& Towns, D. (2005). Verifying the multi-dimensional nature of metropolitan land use: Advancing the understanding and measurement of sprawl. Journal of Urban Affairs, 27(3), 235-259. https://doi.org/10.1111/j.0735-2166.2005. 00235.x

Deng, X., Huang, J., Rozelle, S., \& Uchida, E. (2008). Growth, population and industrialization, and urban land expansion of China. Journal of Urban Economics, 63(1), 96-115. https://doi.org/10.1016/j.jue.2006.12.006

Deng, X., Huang, J., Rozelle, S., \& Uchida, E. (2010). Economic growth and the expansion of urban land in China. Urban Studies, 47(4), 813-843. https://doi.org/10.1177/ 0042098009349770

Dijkstra, L., \& Poelman, H. (2014). A harmonised definition of cities and rural areas: the new degree of urbanisation. Regional working paper 2014. Regional and urban policy, European commission. https:// ec.europa.eu/regional_policy/en/information/publi cations/working-papers/2014/a-harmonised-defin 
ition-of-cities-and-rural-areas-the-new-degree-of-urban isation.

Dupras, J., Marull, J., Parcerisas, L., Coll, F., Gonzalez, A., Girard, M., \& Tell, E. (2016). The impacts of urban sprawl on ecological connectivity in the Montreal Metropolitan Region. Environmental Science and Policy, 58, 61-73. https://doi.org/10.1016/j.envsci.2016.01.005

EC. (2011). Communication from the commission to the European parliament, the council, the European economic and social committee and the committee of the regions: Roadmap to a resource efficient Europe. European commission, $\operatorname{COM}(2011)$ 571. http://eur-lex.europa.eu/legal-content/ EN/TXT/?uri=CELEX:52011DC0571.

EEA. (2006). Urban sprawl in Europe: The ignored challenge. Report No 10/2006. Office for official publications of the European communities; Luxembourg. Available from: http://www.eea.europa.eu/publications/eea_report_2006_ 10.

EEA. (2020a). Land take in Europe. European environment agency. Available at: https://www.eea.europa.eu/data-andmaps/indicators/land-take-3/assessment.

EEA. (2020b). Land take and net land take. European environment agency. Available at: https://www.eea.europa. eu/data-and-maps/dashboards/land-take-statistics\# tab-based-on-data.

Eigenbrod, F., Bell, V. A., Davies, H. N., Heinemeyer, A., Armsworth, P. R., \& Gaston, K. J. (2011). The impact of projected increases in urbanization on ecosystem services. Proceedings of the Royal Society B, 278(1722), 32013208. https://doi.org/10.1098/rspb.2010.2754

Eurostat. (2020a). Land covered by artificial surfaces by NUTS2 regions (lan_lcv_art). https://appsso.eurostat.ec. europa.eu/nui/show.do?dataset=lan_lcv_art

Eurostat. (2020b). https://ec.europa.eu/eurostat/web/gisco/ geodata/reference-data/administrative-units-statisticalunits/nuts.

Eurostat. (2020c). Population on 1 January by age group, sex and NUTS 3 region (demo_r_pjangrp3). https://appsso. eurostat.ec.europa.eu/nui/show.do?dataset=demo_r_pjana ggr3

Eurostat. (2020d). Gross domestic product (GDP) at current market prices by NUTS 3 regions (nama_10r_3gdp). http://appsso.eurostat.ec.europa.eu/nui/show.do?dataset= nama_10r_3gdp

Galster, G., Hanson, R., Ratcliffe, M. R., Wolman, H., Coleman, S., \& Freihage, J. (2001). Wrestling sprawl to the ground: Defining and measuring an elusive concept. Housing Policy Debate, 12(4), 681-717. https://doi.org/ 10.1080/10511482.2001.9521426

Gardi, C., Panagos, P., van Liedekerke, M., Bosco, C., \& De Brogniez, D. (2015). Land take and food security: Assessment of land take on the agricultural production in Europe. Journal of Environmental Planning and Management, 58(5), 898-912. https://doi.org/10.1080/09640568. 2014.899490

Guastella, G., Pareglio, S., \& Sckokai, P. (2017). A spatial econometric analysis of land use efficiency in large and small municipalities. Land Use Policy, 63, 288-297. https://doi.org/10.1016/j.landusepol.2017.01.023

Haase, D., \& Nuissl, H. (2007). Does urban sprawl drive changes in the water balance and policy? The case of
Leipzig (Germany) 1870-2003. Landscape and Urban Planning, 80(1-2), 1-13. https://doi.org/10.1016/j.landu rbplan.2006.03.011

Heimlich, R.E., \& Anderson, W.D. (2001). Developing the urban fringe and beyond: impacts on agriculture and rural land. Report Number 803. USDA Economic Research Service: Washington, DC.

Huang, S. L., Wang, S. H., \& Budd, W. W. (2009). Sprawl in Taipei's peri-urban zone: Responses to spatial planning and implications for adapting global environmental change. Landscape and Urban Planning, 90(1-2), 20-32. https://doi.org/10.1016/j.landurbplan.2008.10.010

Irwin, E. G., \& Bockstael, N. E. (2004). Land use externalities, open space preservation, and urban sprawl. Regional Science and Urban Economics, 34(6), 705-725. https://doi. org/10.1016/j.regsciurbeco.2004.03.002

Kaza, N. (2020). Landscape shape adjusted compactness index for urban areas. GeoJournal. https://doi.org/10.1007/ s10708-020-10262-9

Kuang, W., Chi, W., Lu, D., \& Dou, Y. (2014). A comparative analysis of megacity expansions in China and the U.S.: Patterns, rates and driving forces. Landscape and Urban Planning, 132, 121-135. https://doi.org/10.1016/j.landu rbplan.2014.08.015

Laidley, T. (2016). Measuring sprawl: A new index, recent trends, and future research. Urban Affairs Review, 52(1), 66-97. https://doi.org/10.1177/1078087414568812

Lopez, R., \& Hynes, H. P. (2003). Sprawl in the 1990s: Measurement, distribution, and trends. Urban Affairs Review, 38(3), 325-355. https://doi.org/10.1177/1078087402 238805

Lorenz, K., \& Lal, R. (2009). Biogeochemical C and N cycles in urban soils. Environment International, 35(1), 1-8. https://doi.org/10.1016/j.envint.2008.05.006

Marshall, J. D. (2007). Urban land area and population growth: A new scaling relationship for metropolitan expansion. Urban Studies, 44(10), 1889-1904. https://doi.org/10. 1080/00420980701471943

McDonald, R. I., Forman, R. T. T., \& Kareiva, P. (2010). Open space loss and land inequality in United States'cities, 1990-2000. PLoS ONE, 5(3), e9509. https://doi.org/10. 1371/journal.pone.0009509

Müller, K., Steinmeier, C., \& Küchler, M. (2010). Urban growth along motorways in Switzerland. Landscape and Urban Planning, 98(1), 3-12. https://doi.org/10.1016/j. landurbplan.2010.07.004

Munafo', M., Salvati, L., \& Zitti, M. (2013). Estimating soil sealing rate at national level-Italy as a case study. Ecological Indicators, 26, 137-140. https://doi.org/10.1016/j. ecolind.2012.11.001

Munafo', M. (2020). Consumo di suolo, dinamiche territoriali e servizi ecosistemici. Edizione 2020. Report SNPA 15/20.

Neuman, M. (2005). The compact city fallacy. Journal of Planning Education and Research, 25(1), 11-26. https://doi. org/10.1177/0739456X04270466

Nuissl, H., \& Schroeter-Schlaack, C. (2009). On the economic approach to the containment of land consumption. Environmental Science and Policy, 12(3), 270-280. https://doi. org/10.1016/j.envsci.2009.01.008

Orsi, F. (2018). How densely populated and green are the places we live in? A study of the ten largest US cities. 
Land Use Policy, 76, 300-316. https://doi.org/10.1016/j. landusepol.2018.05.015

Orsi, F. (2019). Centrally-located yet close to nature: A prescriptive agent-based model for urban design. Computers, Environment and Urban Systems, 73, 157-170. https://doi. org/10.1016/j.compenvurbsys.2018.10.001

Ortuño-Padilla, A., \& Fernandez-Aracil, P. (2013). Impact of fuel price on the development of the urban sprawl in Spain. Journal of Transport Geography, 33, 180-187. https://doi.org/10.1016/j.jtrangeo.2013.10.004

Oueslati, W., Alvanides, S., \& Garrod, G. (2015). Determinants of urban sprawl in European cities. Urban Studies, 52(9), 1594-1614. https://doi.org/10.1177/0042098015577773

Paulsen, K. (2014). Geography, policy or market? New evidence on the measurement and causes of sprawl (and infill) in US metropolitan regions. Urban Studies, 51(12), 2629-2645. https://doi.org/10.1177/0042098013512874

Pileri, P., \& Maggi, M. (2010). Sustainable planning? First results in land uptakes in rural, natural and protected areas: The Lombardia case study (Italy). Journal of Land Use Science, 5(2), 105-122. https://doi.org/10.1080/ 1747423X.2010.481078

Pouyat, R., Groffman, P., Yesilonis, I., \& Hernandez, L. (2002). Soil carbon pools and fluxes in urban ecosystems. Environmental Pollution, 116(1), S107-S118. https://doi.org/ 10.1016/S0269-7491(01)00263-9

Romano, B., Zullo, F., Fiorini, L., Ciabo', S., \& Marucci, A. (2017). Sprinkling: An approach to describe urbanization dynamics in Italy. Sustainability, 9(1), 97. https://doi.org/ 10.3390/su9010097

Romano, B., Zullo, F., Fiorini, L., Marucci, A., \& Ciabo', S. (2017). Land transformation of Italy due to half a century of urbanization. Land Use Policy, 67, 387-400. https:// doi.org/10.1016/j.landusepol.2017.06.006

Salvati, L. (2016). Soil sealing, population structure and the socioeconomic context: A local-scale assessment. GeoJournal, 81, 77-88. https://doi.org/10.1007/ s10708-014-9608-0

Science for Environment Policy. (2016). No net land take by 2050? Future brief 14. Produced for the European commission DG environment by the science communication unit, UWE, Bristol. Available at: http://ec.europa.eu/scien ce-environment-policy.

Siedentop, S., \& Fina, S. (2012). Who sprawls most? Exploring the patterns of urban growth across 26 European countries. Environment and Planning A: Economy and Space, 44(11), 2765-2784. https://doi.org/10.1068/a4580

Sun, X., Crittenden, J. C., Li, F., Lu, Z., \& Dou, X. (2018). Urban expansion simulation and the spatio-temporal changes of ecosystem services, a case study in Atlanta Metropolitan area, USA. Science of the Total Environment, 622-623, 974-987.
Suriya, S., \& Mudgal, B. V. (2012). Impact of urbanization on flooding: The Thirusoolam sub watershed-A case study. Journal of Hydrology, 412-413, 210-219. https://doi.org/ 10.1016/j.jhydrol.2011.05.008

Tian, G., \& Wu, J. (2015). Comparing urbanization patterns in Guangzhou of China and Phoenix of the USA: The influences of roads and rivers. Ecological Indicators, 52, 23-30. https://doi.org/10.1016/j.ecolind.2014.11.024

UN. (2017a). The sustainable development goals report 2017. New York: United Nations.

UN. (2017b). Work of the statistical commission pertaining to the 2030 agenda for sustainable development (A) RES/71/313). New York: United Nations.

Wang, M., Krstikj, A., \& Koura, H. (2017). Effects of urban planning on urban expansion control in Yinchuan City, Western China. Habitat International, 64, 85-97. https:// doi.org/10.1016/j.habitatint.2017.04.008

Wassmer, R. W. (2006). The influence of local urban containment policies and statewide growth management on the size of United States urban areas. Journal of Regional Science, 46(1), 25-65. https://doi.org/10.1111/j.0022-4146. 2006.00432.x

Weilenmann, B., Seidl, I., \& Schulz, T. (2017). The socioeconomic determinants of urban sprawl between 1980 and 2010 in Switzerland. Landscape and Urban Planning, 157, 468-482. https://doi.org/10.1016/j.landurbplan.2016. 08.002

Zambon, I., \& Salvati, L. (2020). Unraveling latent transformations in metropolitan structures: A local-scale analysis of urban landscapes and social functions. GeoJournal, 85, 863-881. https://doi.org/10.1007/s10708-019-09996-y

Zhang, Q., \& Su, S. (2016). Determinants of urban expansion and their relative importance: A comparative analysis of 30 major metropolitans in China. Habitat International, 58, 89-107. https://doi.org/10.1016/j.habitatint.2016.10. 003

Zoppi, C., \& Lai, S. (2014). Land-taking processes: An interpretive study concerning an Italian region. Land Use Policy, 36, 369-380. https://doi.org/10.1016/j.landusepol. 2013.09.011

Zoppi, C., \& Lai, S. (2015). Determinants of land take at the regional scale: A study concerning Sardinia (Italy). Environmental Impact Assessment Review, 55, 1-10. https:// doi.org/10.1016/j.eiar.2015.06.002

Publisher's Note Springer Nature remains neutral with regard to jurisdictional claims in published maps and institutional affiliations. 